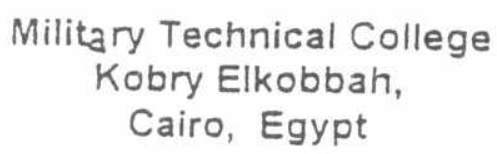

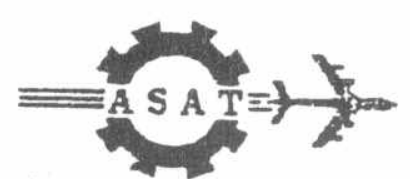

$8^{\text {In }}$ Intemational Conference on Aerospace Sciences \& Aviation Technology

\title{
EFFECT OF NICKEL CONTENT ON MICROSTRUCTURE AND MECHANICAL PROPERTIES OF AUSTEMPERED DUCTILE CAST IRON
}

\author{
M. M. EL-HISSY*, G. M. ABDO ${ }^{\star *}$, B.A.EL-SARNAGAWI ${ }^{* \star *}$
}

\begin{abstract}
Alloyed ductile Cast iron samples were produced using induction coreless furnace. The designed alloys have the following composition $(3.4-3.8 \% \mathrm{C}$, 2.3-2.7\% Si , 0.15-0.54\% Mn , $0.02 \% \mathrm{~S}, 0.02 \% \mathrm{p}, 0.4-0.5 \% \mathrm{Mo}$ and variable $\mathrm{Ni}$ content from $0.5-4 \%$ ) The austempering heat treatment was performed using Salt bath furnaces, at a temperature of $900^{\circ} \mathrm{c}$ for $30 \mathrm{~min}$. and the isothermal transformation was carried out at temp. of $220^{\circ} \mathrm{C}$ and $400^{\circ} \mathrm{C}$. Austempering transformation time was varied from $10 \mathrm{~min}$. to 24 hrs. to investigate its effect on the final structure and mechanical properties.

The results showed that, the best ductility and impact toughness for Austempered alloyed ductile Cast iron at $400^{\circ} \mathrm{C}$ was obtained by holding time equal to $60 \mathrm{~min}$., while the optimum holding time at $220^{\circ} \mathrm{C}$ was $2 \mathrm{hrs}$. More over the alloy containing $0.5 \%$ Mo \& $2-4 \%$ Ni provokes increase in hardenability and mechanical properties.
\end{abstract}

\section{NOMENCLATURE}
C Carbon
Hv Hardness
IT Impact Toughness
Mn Manganese
Mo Molybdenum
$\mathrm{Ni}$ Nickel
P Phosphorus
S Sulpher
Si Silicon
ou Ultimate Tensile Strength
$\delta$ Elongation

(\%)

(Vickers)

(Joute/ $\mathrm{Cm}^{2}$ )

(\%)

$(\%)$

(\%)

(\%)

(\%)

(\%)

(Mpa)

(\%)

* M. Sc. Mech. Eng. Armament Authority, Ministry of Defense, Cairo, Egypt.

** Ph.D. Eng. T. R. C. , Ministry of Defense, Cairo, Egypt.

*** Prof. D. Eng. M . T . C ., Ministry of Defense, Cairo, Egypt. 


\section{INTRUDUCTION}

Austempring ductile cast iron importance in production of highly stressed components competes with low alloyed high quality steel giving comparable mechanical properties, fig . 1 better machinability, high castability and shorter time for heat treatment.

Austempring treatment is applied when bainitic matrix is desired. Bainite is a term applied primarily to those transformation products of austenite that form at temperatures between those at which pearlite and martensite form. In steels, austempring results in a bainitc structure normally consisting of acicular ferrite with carbides.

However, in cast Iron, precipitation of the carbide phase is suppressed due to the high silicon content and a lamellar structure of acicular ferrite and high carbon austenite is obtained [2].

The best mechanical properties are obtained by the first method [4].

Nodular iron is austenitized at a temperature between $850^{\circ} \mathrm{C}$ and $950^{\circ} \mathrm{C}$. The holding time at this temperature depends on the alloying elements present and ranges from $15 \mathrm{~min}$. to $5 \mathrm{hrs}$. Part of the graphite dissolves in the austenite up till matrix is carbon saturated. Thus, the carbon content of the matrix after austenitization depends on the austenitization temperature and the holding time. The amount of carbon in the austenite that is in equilibrium with the graphite increases with increasing the austenitization temperature, and is also influenced by the chemical composition of alloy.

During austempering, acicular ferrite plates grow in the austenite. The ferrite nucleates on suitable sites at the grain boundaries and at interface between austenite and graphite. Due to the ferrite formation, the carbon is rejected from the ferrite into the surrounding austenite. High silicon content suppresses the cementite phase normally associated with baintic transformation and a carbon-enriched stabilized austenite remains. This cementite - free bainite forms at temperature ranging from $175^{\circ} \mathrm{C}$ and it can contain large amounts (up to $50 \%$ ) of retained austenite which, because of its high carbon content, is stable to temperatures below $\left.-80^{\circ} \mathrm{C} \| 6\right]$. The arnount of retained austenite increases with the increase of the austenitization temperature due to higher carbon before quenching [5].

Austempring at temperature of $370^{\circ} \mathrm{C}$ or higher produces a course structure of acicular ferrite needles in austenite at lower temperatures. The structures are much finer and resemble typical bainites having alternate platelets of ferrite and austenite. The ferrite austenite spacing decreases with decreasing the transformation temperature due to the close relation between structure and mechanical properties, it is understandable that strength and toughness of baintic ductile iron can vary widely. Highest tensile strength and relatively small elongation are obtained zone. Increasing the austempering temperatures results in a gradual decrease in the ultimate tensile strength and elongation. However increase and passes through a maximum [6].

Some investigator [7], [8] have shown that extended holding time during austempering causes a reduction of ductility and impact toughness. Increasing austempering time form one hour to two hours at $375^{\circ} \mathrm{C}$ is 


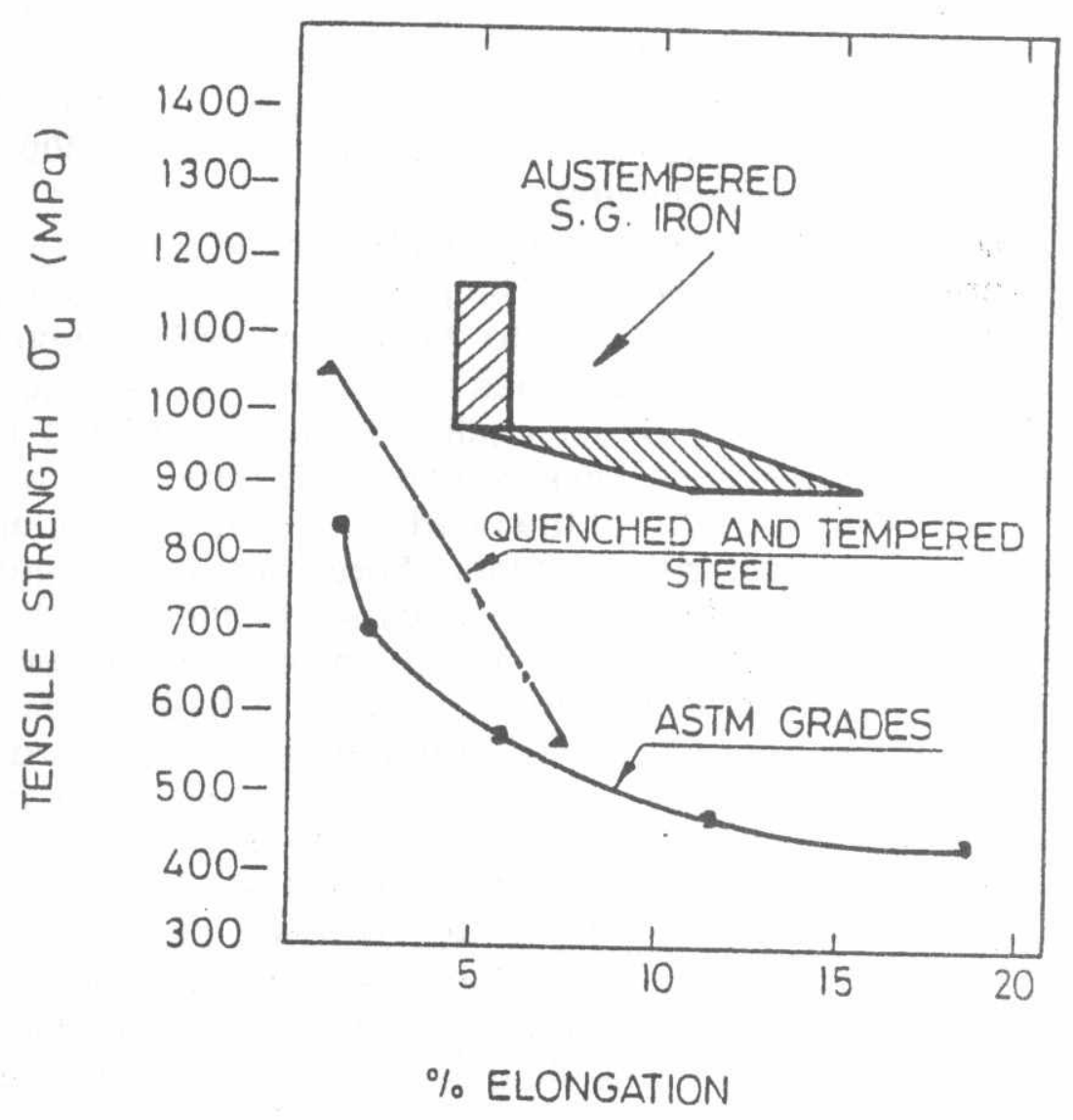

Fig.1. Comparison of austempered nodular irons to current standard grades of nodular iron [1] 
sufficient to reduce elongation and toughness by more than $50 \%$ as shown in fig . 2 [7].

The austempering transformation can be considered as two-stage reaction. In the first stage, austenite decomposes to ferrite and carbon-enriched austenite. This is followed by the second stage in which austenite decomposes to ferrite and carbides, as can be seen from fig. 3 Austempering transiormation of steels can be described in the same way, as can be seen from fig .4 the final stage of austenite decomposition to ferrite and carbides has been observed at temperature as low as $300^{\circ} \mathrm{C}$ and has been to occur at even lower temperature.

The addition of alloying elements to the ductile cast iron is esseritial for successful austempering heat treatment. The process of alloying deliays the pearlitic reaction and allows quenching to the austempering temperature without forming pearlite or ferrite. Nickel has a graphitizing character. It can be used in place of silicon to offset chilling tendency. Nickel pearlite structure is reacily annealable. $\mathrm{Ni}$ is weak in refining pearlite, but it acts as a graphitizer, faclitates break down of the pearlite at elevated temperatures during austenifization as shown from the work of previous investigators.

The previous study of hardenability for unalloyed ductile iron by Barta, Dorazil [8] showed poor hardenability, which lowers the possibility of utilization $o^{\prime}$ austempered ductile iron for production of large section sizes and limits the thickness of hardened components. To improve the hardenability of unalloyed ductile cast iron $\mathrm{Ni}$ is added by different amounts. The following comparison of resulting structure and hardness values published by Climax 1982 [9] show the effect of $\mathrm{Ni}$ on the continuous cooling ransformation diagrams. Fig.5. shows the CCT diagram of unalloyec ductile iron - where both pearlitic and bainitic transformation start are within the first minute of cooling so the time delay available for cooling before transformation is limited and the half cooling time for hardened structure is less than $1 \mathrm{~min}$.

This means to obtain hard structures the cooling rate must be high enough to ensure bainitic or martensitic transformation which is about $8^{\circ} \mathrm{C} / \mathrm{sec}$.

This critical rate of cooling cannot be reached for thick sections moie than 10-mm thickness.

The addition of $4.8 \% \mathrm{Ni}+\mathbf{0 . 5 \%}$ Mo increases the hardenability of ductille iron as shown in fig .5.a where the half cooling time of hardened layer $20 \mathrm{~min}$ and critical cooling rate of $0.3^{\circ} \mathrm{C} / \mathrm{sec}$. That allows larger section size during hardening. Structures while $d$ is pearlitic + ferrite

This means better hardenability by higher addition of $\mathrm{Ni}$. The optimum addition of $\mathrm{Ni}$ to the ductile iron alloy is governed by the required critical cooling rate and the section sizes. Higher addition of $\mathrm{Ni}$ decreases the critical cooling rate and allows more thickness of hardened layer. The production of an alloyed ductile cast iron may satisfy the required hardness and strength for highly stressed components. The cast ductile iron does not satisfy these requirements. Austempering heat treatment confirms better combination of mechanical properties, which satisfy the required properties $[10,11,12]$. 


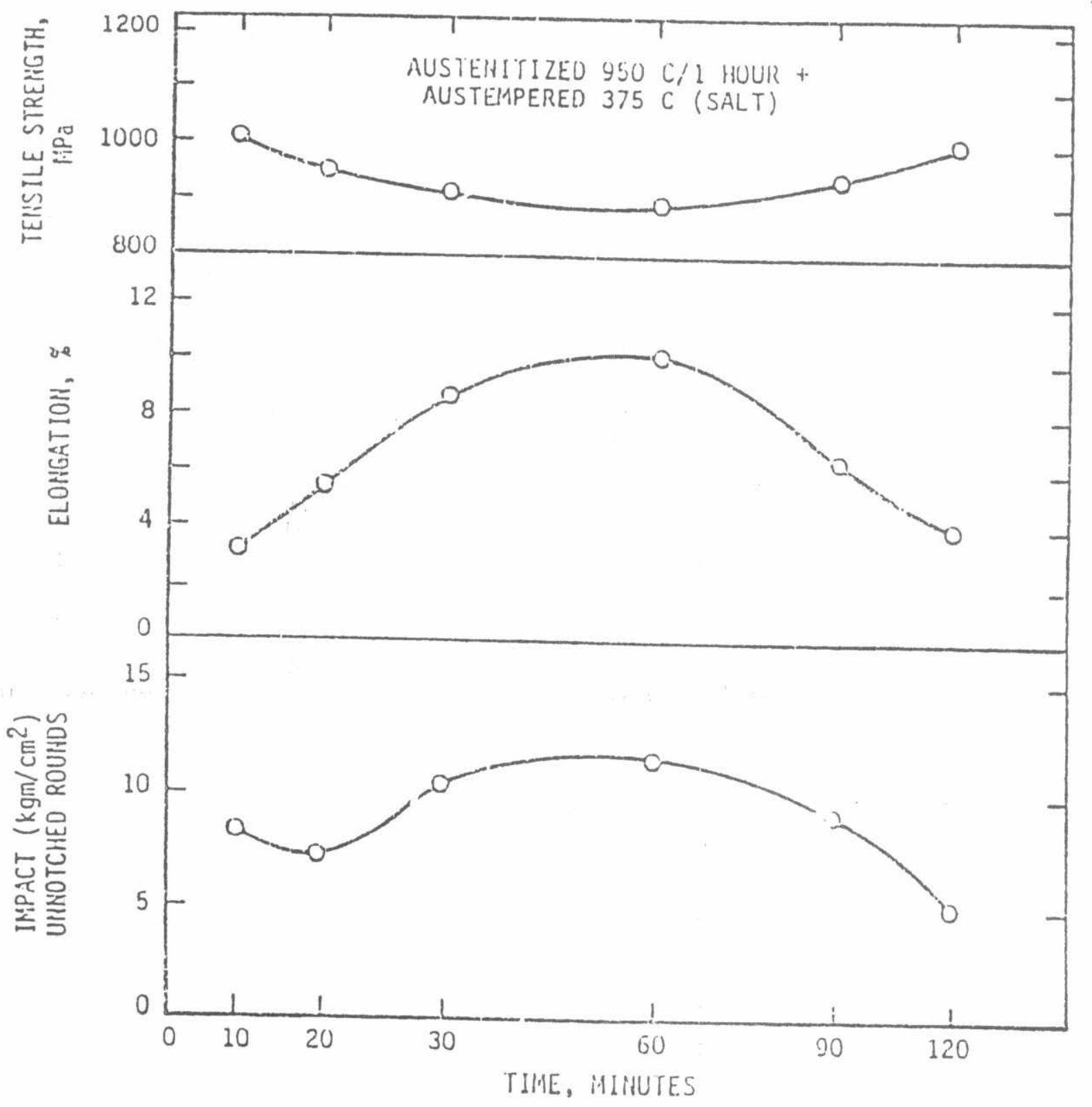

Fig.2. Influence of austempering time on the mechanical properties of unalloyed nodular iron [6] 


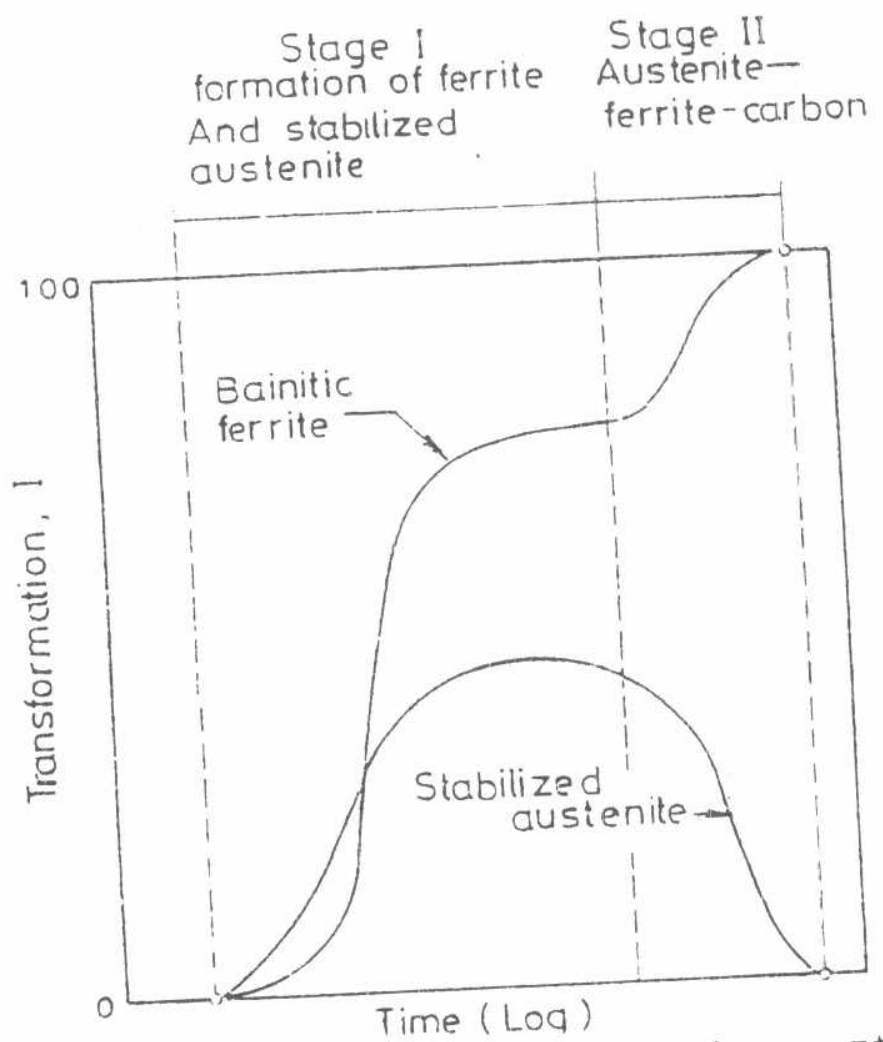

Fig 3. Transformation of austenite during austempering [2]

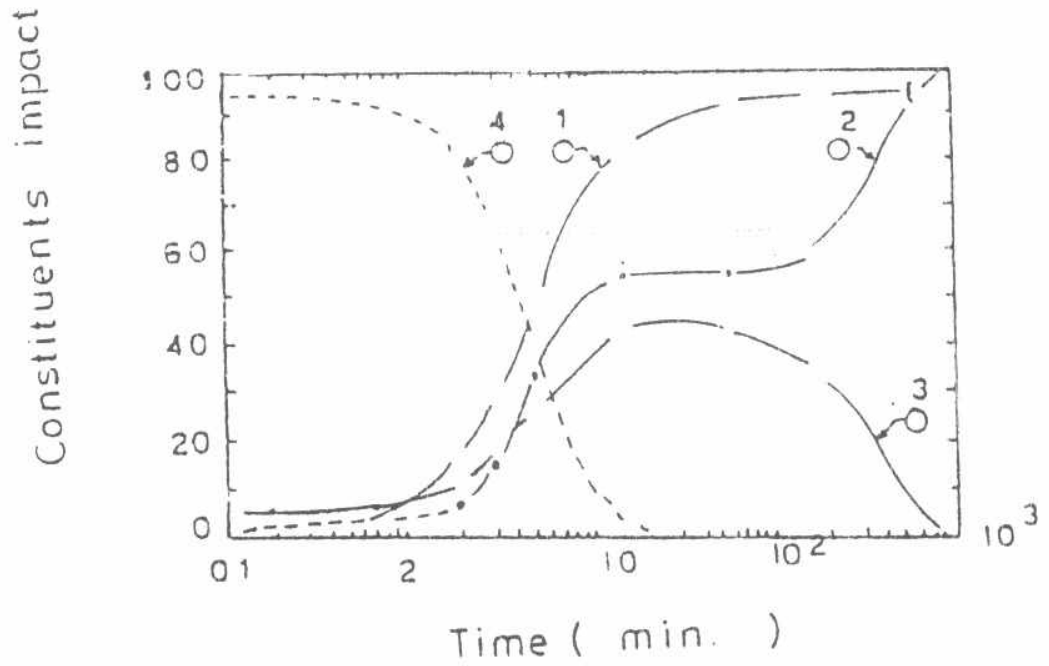

Fig.4.1: Inflence of austempring time on the proportion of various constituents in bainitic silicon steel: 1 - apparent bainite, , 2- transformed austenite 3- retained austenite, and 4-martensite. [3] 


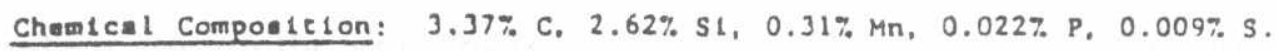
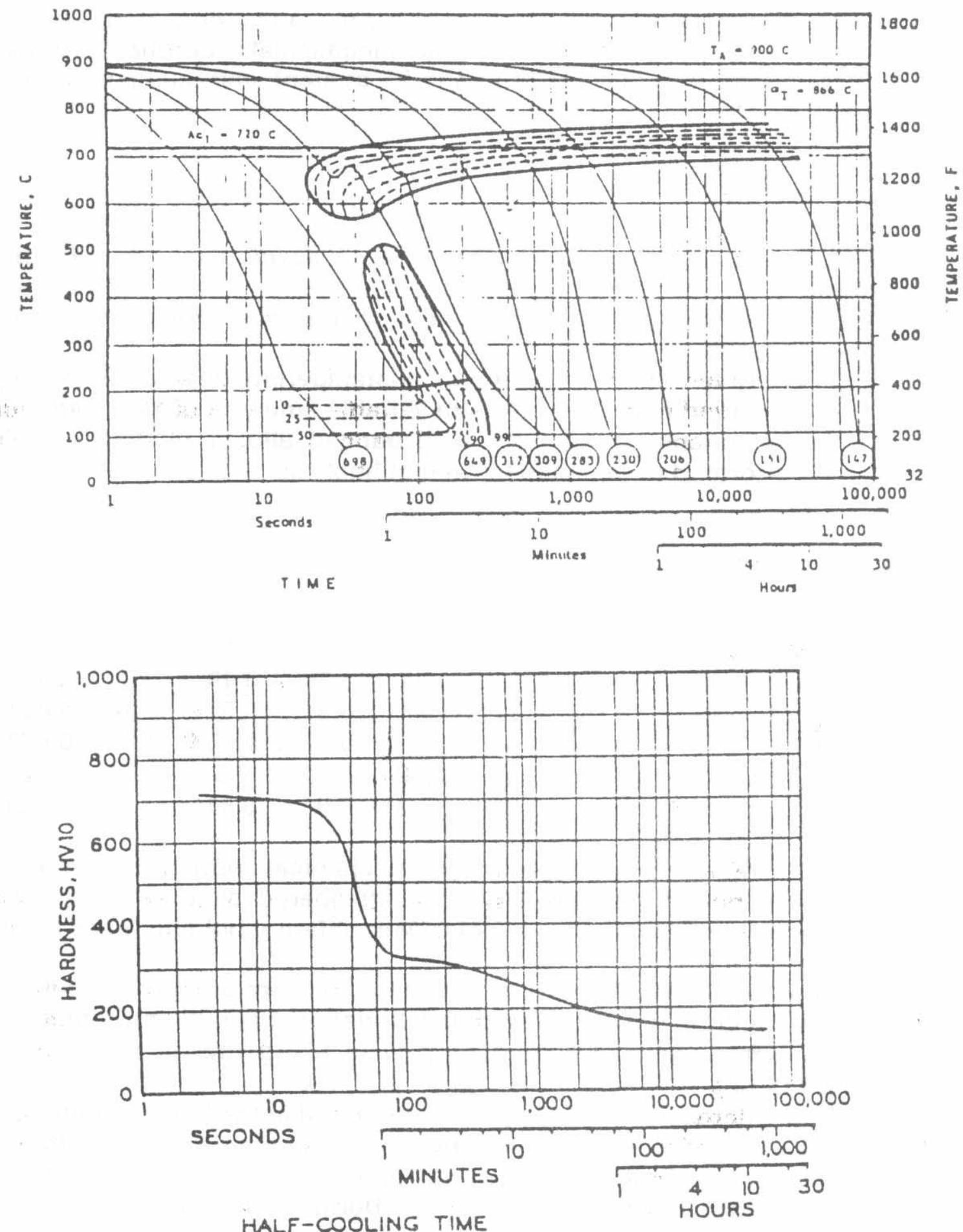

Fig.5. CCT-diagram for unalloyed ductile iron 
The aim of this research work is to study the effect of austemoering isothermal transformation temperature and time on the resulting morphology, and to evaluate various mechanical properties of the alloyed ductile cast iron having different $\mathrm{Ni}$ content and austemperd at different: temperature.

\section{EXPERMENTAL WORK}

The program of experimental work is devided into two main parts as follows:

1 - Production of alloyed ductile cast iron samples using in -- mould process.

2 - Determination of optimum austempering heat treatment cycles for alloyed ductile cast iron with variable amounts of $\mathrm{Ni} \%$ - additions .

The chemical analysis of produced alloyed ductile cast iron were performed in the state by weight analysis

Table 1. Chemical composition of alloyed ductile iron.

\begin{tabular}{|c|c|c|c|c|c|c|c|}
\hline Element & $\mathrm{C} \%$ & $\mathrm{Si} \%$ & $\mathrm{Mn} \%$ & $\mathrm{Mo} \%$ & $\mathrm{Ni} \%$ & $\mathrm{P} \%$ & $\mathrm{~S} \%$ \\
\hline 1 & 3.29 & 2.32 & 0.26 & 0.49 & 0 & 0.02 & 0.01 \\
\hline 2 & 3.32 & 2.41 & 0.31 & 0.51 & 0.49 & 0.023 & 0.011 \\
\hline 3 & 3.34 & 2.25 & 0.32 & 0.48 & 101 & 0.023 & 0.011 \\
\hline 4 & 3.28 & 2.42 & 0.32 & 0.5 & 1.98 & 0.024 & 0.008 \\
\hline 5 & 3.24 & 2.34 & 0.31 & 0.51 & 4.1 & 0.024 & 0.008 \\
\hline
\end{tabular}

The Prepared specimens for mechanical properties (tensile, impact resistance and hardness) were austempered at $220{ }^{\circ} \mathrm{C}$ according to heat treatment cycle shown in fig.6. with different holding times from $10 \mathrm{~min}$ to $24 \mathrm{hr}$.

Samples for microstructure observation were prepared simulatneously for each holding time to detect the variation of microstructure with holding time. After each heat treatment cycle using the micro hardness tester of load $10 \mathrm{gr}$.

The microstructure of samples austempred in the lower bainite region $220^{\circ} \mathrm{C}$ were examined by optical microscope after etching with $4 \%$ nital.

Melting was carried out using $20 \mathrm{~kg}$ capacity induction furnace in the Helwan the Helwan iron fundraises. During melting of the base charge - The unnecessary superheating was prevented in order not to promote carbide formation. The base charge was melted and heated to temperature $1550^{\circ} \mathrm{C}$. The ladle was preheated before ladling. slag skimming of melt surface was performed in the ladle before the addition of the graphitizaing inoculate The graphitizaing inoculation was carried by adding of $75 \% \mathrm{Fe}-\mathrm{Si}$ foundry grade in granular form size $3-5 \mathrm{~mm}$.

The melt was then poured into the mould. The pouring temperature was $1450^{\circ} \mathrm{C}$. 


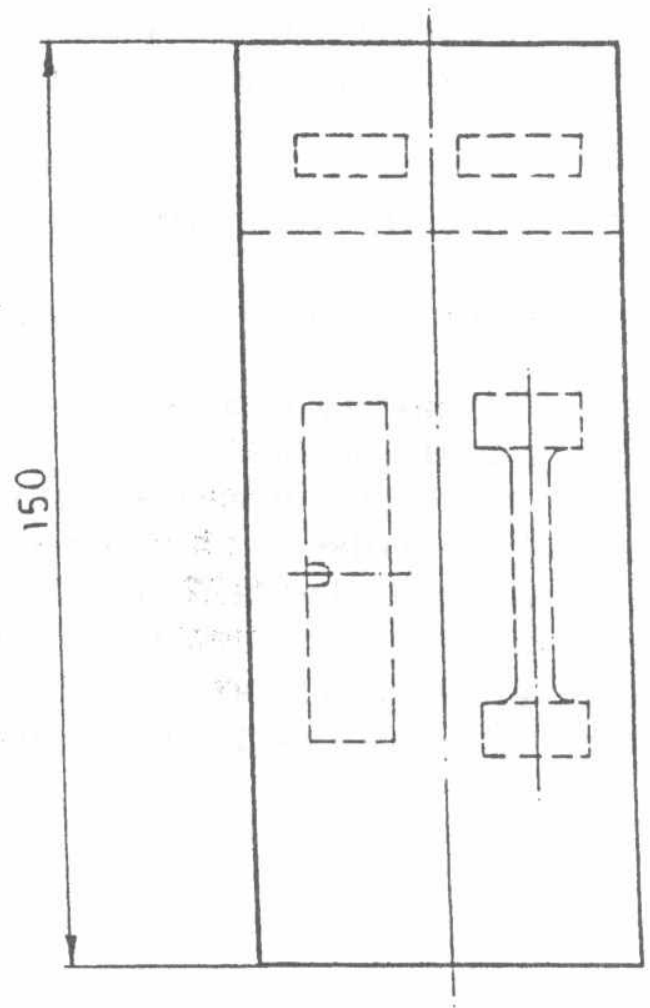

6. STRUCTURE SPECIMENS

2 TENSILE SPECIMENS

2 IMPACT SPECIMENS

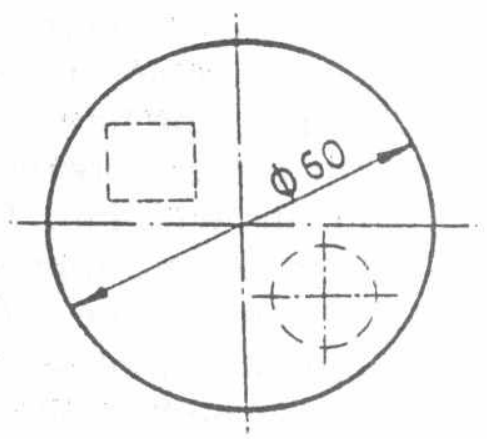

Fig.6. Test samples prepared from the cast bar. 
A chilled cast specimen, for spectral analysis was poured in a metallic mould.

After solidification and cooling of the casting, shaking out and cleaning by sand blast machine.

The test samples were machined from the cast bar according to the drawing shown in fig .6. The following tests were then carried on the prepared specimen:

1 - Determination of the chemical composition by spectrographic analysis of the chilled cast specimen and by weight analysis of specially cut drilling chips.

2 - Optical microscope observation and nodule counting of the produced ductile cast iron

3 - Mechanical properties testing tensile, impact and hardness tests were carried out on standard prepared samples.

To investigate the effect of the subcritical isothermal transformation temperature on the mechanical properties of both upper and lower bainite, two austempring temperatures were selected $\left(220^{\circ} \mathrm{C}, 400^{\circ} \mathrm{C}\right)$

To study the effect of holding time the mechanical properties the test specimens were austemepred at temperature $220^{\circ} \mathrm{C}$ and $400^{\circ} \mathrm{C}$ for 6 different holding times (10 $\mathrm{min}, 30 \mathrm{~min}, 1 \mathrm{hr}, 2 \mathrm{hrs}, 10 \mathrm{hrs}, 24 \mathrm{hrs}$ ) as shown in fig .7. and fig .8 .

\section{RESULTS AND DISCUSSIONS}

The results obtained through out this work can be divided into two main groups :

I - Microstructure observation of austempered alloyed ductile iron.

II- Mechanical properties of austempered alloyed ductile cast iron.

1 - Microstructure observation of austempered alloyed ductile iron:

IIlustrative Microstructure of samples is shown in fig .9. a, b and c. The dark areas represent the apparent bainite amount transformed during holding time while the white areas represent the retained austenite which is not transformed during austempring. The apparent bainite areas are composed of lower bainite plates appearing in the needle form and retained austenite captured between the bainite plates.

Microstructure observation of samples austempered at $400^{\circ} \mathrm{C}$, (upper bainite region) in fig.10. a, b and c. the upper bainite structure is more coarse than observed lower bainite. It has a feathery like structure arranged in stacks of parallel lathes or needles of bainite.

II - Mechanical properties of austempered alloyed ductile cast iron.

The tensile properties of austempered alloyed ductile cast iron were tested using standard tensile test specimens $8.76 \times 35 \mathrm{~mm}$. For each austempring temperature table (3) austempered alloyed ductile cast iron at $400^{\circ} \mathrm{C}$ all samples were tested by the universal testing machine INSTRON 8032 at room temperature $25^{\circ} \mathrm{C}$ and relative humidity $60 \%$ The 


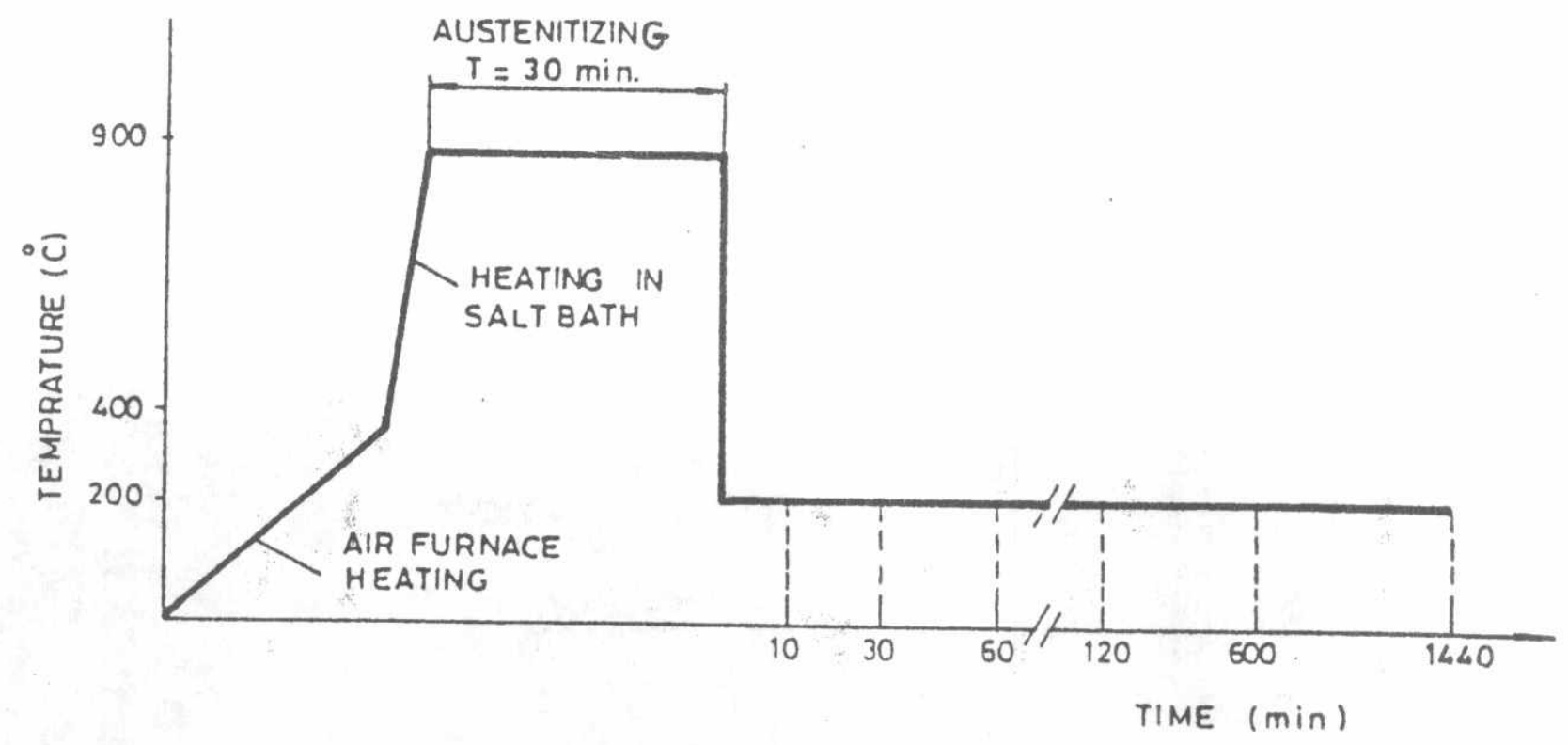

Fig.7. Representation $f$ the applied austempering thermal cycle $\left(220^{\circ} \mathrm{C}\right)$

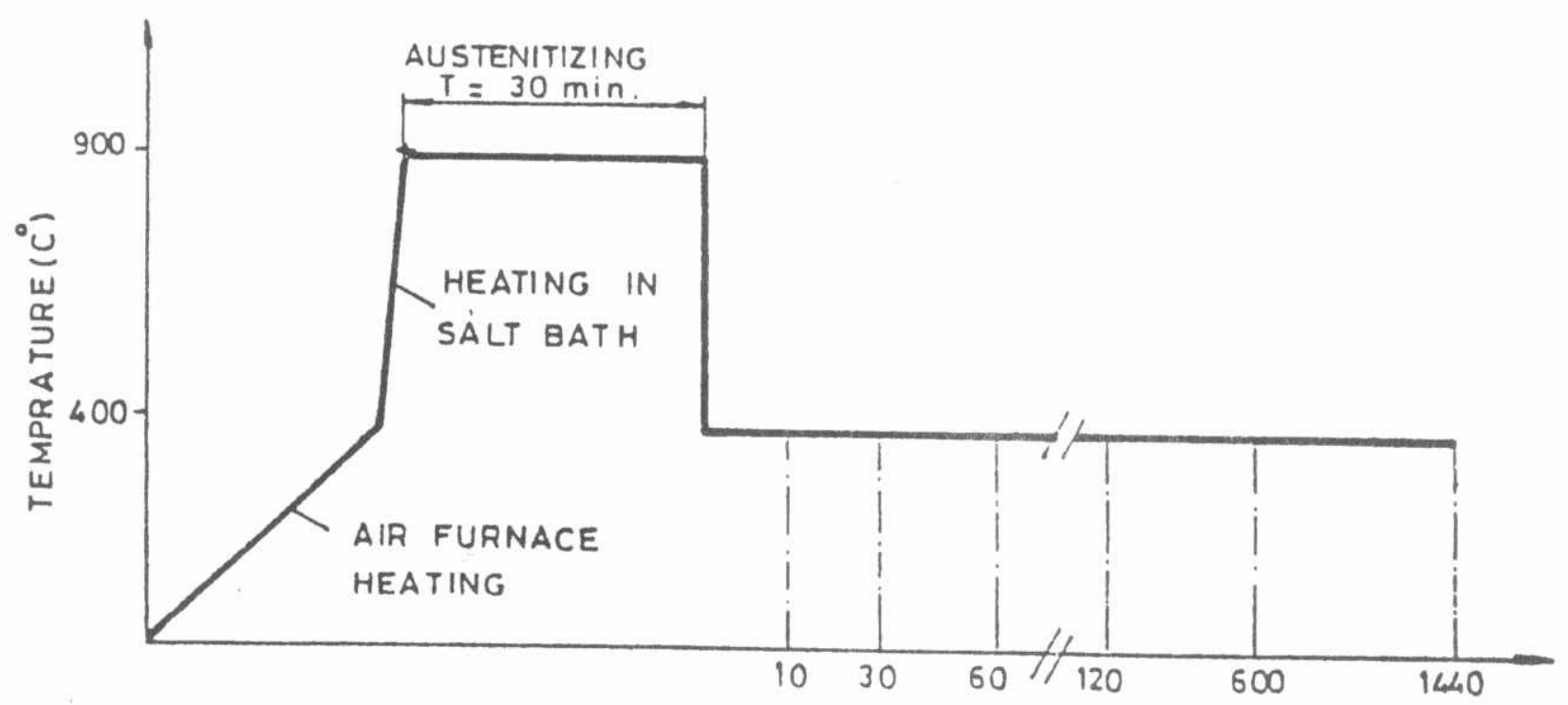

$\operatorname{TIME}(\mathrm{m} \mid \mathrm{n})$

Fig.8. Representation of the applied austempering thermal cycle $\left(400^{\circ} \mathrm{C}\right)$ 


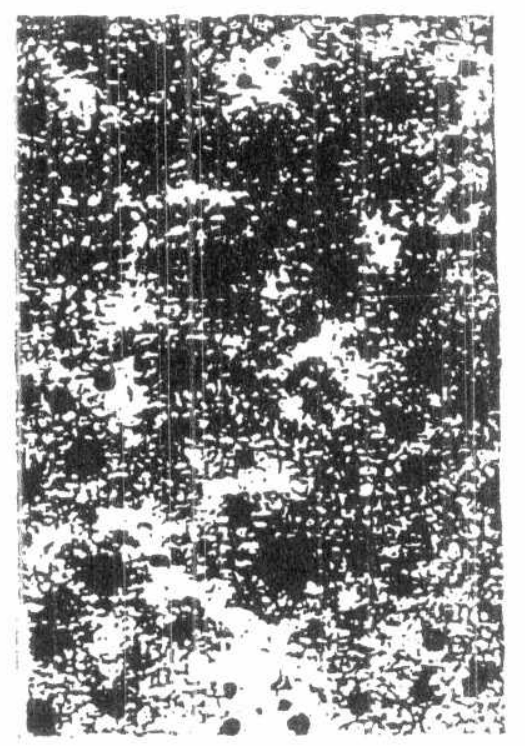

$4 \%$ Nital $100 x$

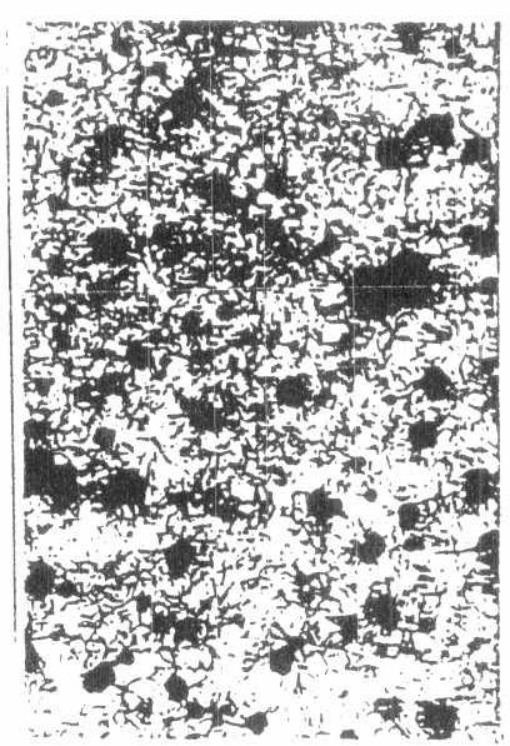

$4 \%$ Nital

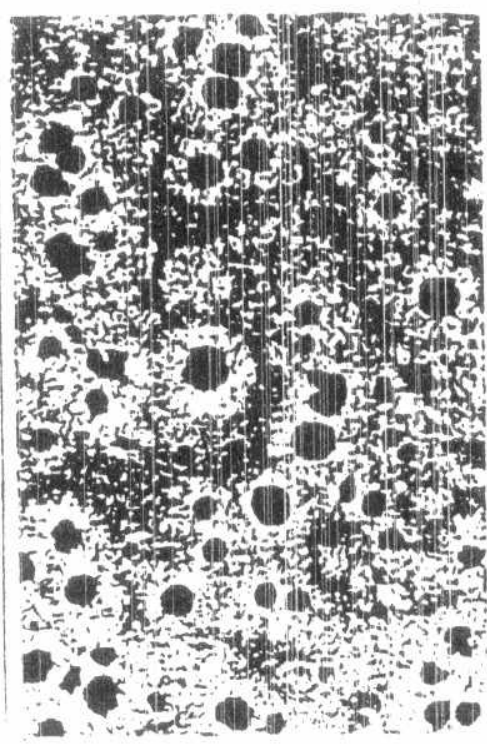

4\% Nital $100 \mathrm{X}$
(A) $0.5 \% \mathrm{Ni}$
(B) $1 \% \mathrm{Ni}$
(C) $4 \pi \mathrm{Ni}$

Fig 9. Effect of $\mathrm{Ni}$ content on microstructure variation of: lower bainite austempered ductile iron austempering temperature $220^{\circ} \mathrm{C}$, austempering time $10 \mathrm{~min}$. 


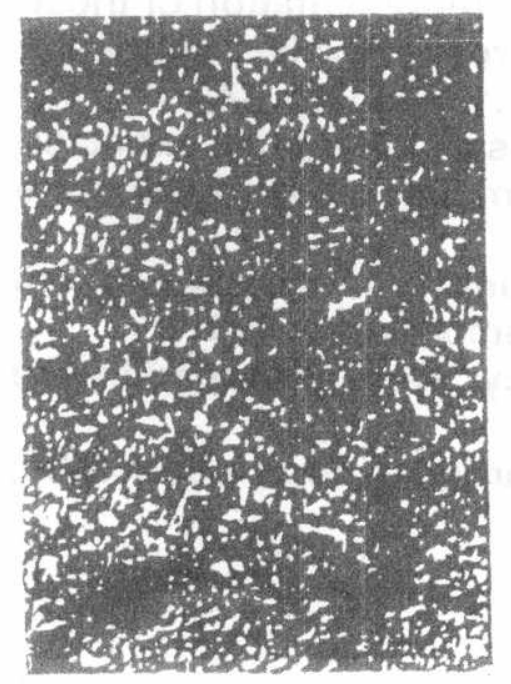

47 Nital $500 x$

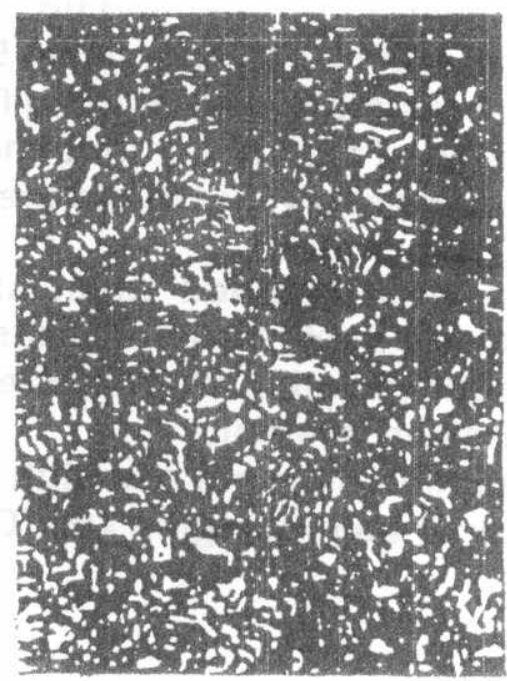

$4 \approx$ Nital

$500 \times$

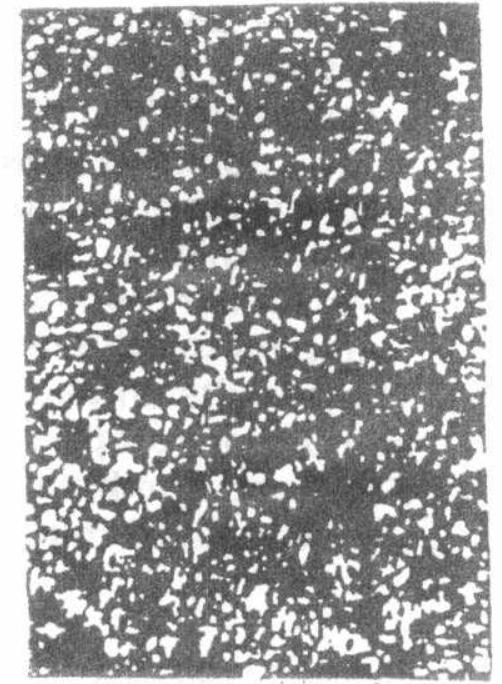

$4 \%$ Nital $500 \mathrm{X}$

(B) $1 \% \mathrm{Ni}$

(C) $4 \% \mathrm{Ni}$

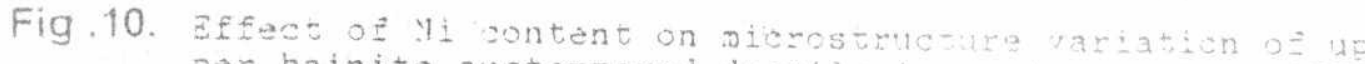
per bainite austempered duotile iron bemperzture ino zustampering time 30 min 
results of mechanical properties for lower bainite samples and upper bainite are represented graphically in fig .11. and fig .12 .

Form the results of tensile testing and micro-hardness testing lower bainite samples austempered at $220{ }^{\circ} \mathrm{C}$ with different holding times, Its clear that the ultimate tensile strength is increasing by increasing the holding time till reaching maximum value at two hours.

Future increase of holding time gives no significant change in tensile strength. The hardness curve shows decrease in hardness by increasing holding time reaching a minimum after two hours.

Future more than two hours at $220^{\circ} \mathrm{C}$ will increase the hardness slightly. The result of impact toughness tests for alloyed ductile cast iron samples austempered at $220^{\circ} \mathrm{C}$ and $400{ }^{\circ} \mathrm{C}$ with variable holding times from 10 $\min -24$ hrs. are shown in fig.13. and fig.14. representation of these results are shown in table 4. and table 5. respectively, graphical representation of these results is shown in fig fig .13. and fig .14.

The obtained peak value of the impact toughness at $120 \mathrm{~min}$. is expected to correspond to a maximum value of the the amount retained austenite in the matrix .

A similar behavior is also obtained when styling the variation of the impact toughness value of ductile iron with austempering at $400{ }^{\circ} \mathrm{C}$.

The results Impact toughness should consistency were governed by the amount of soft phase retained austenite.

For best combination of high strength and high hardness choice of holding time will be $60 \mathrm{~min}$. at upper bainite region $400^{\circ} \mathrm{C}$.

\section{CONCLUSIONS}

From these research work we can come to the following conclusion :

1 - Best ductility and impact toughness foe austemperd alloyed ductile cast iron at $400^{\circ} \mathrm{C}$ was obtained by holding time equal $60 \mathrm{~min}$. The addition of $4 \% \mathrm{Ni}$ increased the impact toughness levell to 154 joule/ $\mathrm{cm}^{2}$ which ropresent $25 \%$ increase compared with unalloyed ductile cast iron, austempered at $400^{\circ} \mathrm{C}$ for $1 \mathrm{hr}$. holding time $\left(130\right.$ joule $\left./ \mathrm{cm}^{2}\right)$.

2 - The optimum holding time at (lower bainite region) $220^{\circ} \mathrm{C}$ was $2 \mathrm{hrs}$ giving the maximum possible $\sigma$ and reasonable Hv. For highly stressed components.

Addition of $4 \% \mathrm{Ni}$ increased both the obtained maximum strength and ductility.

3 - Addition of $0.5 \%$ Mo and $2-4 \%$ Ni showed increase in hardenability of ductile cast iron if compared with unalloyed one, allowing austempering of large section sizes reaching $(35-50 \mathrm{~mm})$

\section{ACKNOWLEDGEMENTS}

The authors would like to acknowledge prof.Dr. M. A. EL-Salmon. For his continuous support with interesting technical discussions and useful suggestions. 
Table 2. Mechanical Properties of Austempered Alloyed Ductile Iron after Holding Time At $220^{\circ} \mathrm{C}$

\begin{tabular}{|c|c|c|c|c|c|c|c|}
\hline \multirow{2}{*}{$\begin{array}{c}\mathrm{Ni} \% \\
\text { Content }\end{array}$} & \multirow{2}{*}{$\begin{array}{l}\text { Mechanical } \\
\text { Properties }\end{array}$} & \multicolumn{6}{|c|}{ Holding time } \\
\hline & & $10 \mathrm{~min}$ & $30 \mathrm{~min}$ & $1 \mathrm{hr}$ & $2 \mathrm{hrs}$ & $10 \mathrm{hrs}$ & $24 \mathrm{hrs}$ \\
\hline \multirow{3}{*}{0.0} & ou Mpa & 860 & 960 & 1230 & 1240 & 1240 & 1240 \\
\hline & $6 \%$ & 0.9 & 1.8 & 3.0 & 4.0 & 2.0 & 1.0 \\
\hline & Hv10 & 600 & 580 & 530 & 470 & 480 & 500 \\
\hline \multirow{3}{*}{0.5} & ou Mpa & 870 & 1000 & 1240 & 1250 & 1250 & 1250 \\
\hline & $\delta \%$ & 1.1 & 2.0 & 3.5 & 5.0 & 2.5 & 2.0 \\
\hline & Hv10 & 620 & 600 & 550 & 490 & 500 & 510 \\
\hline \multirow{3}{*}{1.0} & ou Mpa & 880 & 1100 & 1250 & 1280 & 1280 & 1280 \\
\hline & $\delta \%$ & 1.3 & 2.2 & 4.0 & 5.5 & 3.0 & 2.0 \\
\hline & Hv10 & 640 & 620 & 570 & 510 & 520 & 550 \\
\hline \multirow{3}{*}{2.0} & $\delta \%$ & 900 & 1220 & 1270 & 1300 & 1300 & 1300 \\
\hline & $\delta \%$ & 1.5 & 2.5 & 4.5 & 6.0 & 3.5 & 3.5 \\
\hline & Hv10 & 660 & 640 & 290 & 530 & 540 & 550 \\
\hline \multirow{3}{*}{4.0} & ou Mpa & 910 & 1250 & 1290 & 1350 & 1350 & 1350 \\
\hline & $8 \%$ & 1.7 & 3.0 & 5.0 & 6.5 & 4.0 & 3.0 \\
\hline & Hv10 & 680 & 660 & 610 & 550 & 560 & 570 \\
\hline
\end{tabular}

Table 3. Mechanical Properties of Austempered Alloyed Ductile Iron after Holding Time At $400{ }^{\circ} \mathrm{C}$

\begin{tabular}{|c|c|c|c|c|c|c|c|}
\hline \multirow{2}{*}{$\begin{array}{c}\mathrm{Ni} \% \\
\text { Content }\end{array}$} & \multirow{2}{*}{$\begin{array}{l}\text { Mechanical } \\
\text { Properties }\end{array}$} & \multicolumn{6}{|c|}{ Holding time } \\
\hline & & $10 \mathrm{~min}$ & $30 \mathrm{~min}$ & $1 \mathrm{hr}$ & $2 \mathrm{hrs}$ & $10 \mathrm{hrs}$ & 24 hrs \\
\hline \multirow{3}{*}{0.0} & ou Mpa & 765 & 900 & 940 & 950 & 890 & 820 \\
\hline & $8 \%$ & 1.6 & 4.5 & 7.0 & 5.0 & 3.5 & 3.3 \\
\hline & Hv10 & 365 & 315 & 290 & 295 & 300 & 310 \\
\hline \multirow{3}{*}{0.5} & ou Mpa & 780 & 830 & 960 & 970 & 915 & 850 \\
\hline & $\delta \%$ & 1.7 & 5.0 & 7.0 & 6.0 & 4.0 & 3.2 \\
\hline & Hv10 & 390 & 330 & 300 & 305 & 320 & 350 \\
\hline \multirow{3}{*}{1.0} & ou Mpa & 800 & 850 & 980 & 990 & 935 & 860 \\
\hline & $\delta \%$ & 1.8 & 5.5 & 8.0 & 7.0 & 4.5 & 3.8 \\
\hline & Hv10 & 410 & 350 & 320 & 325 & 340 & 360 \\
\hline \multirow{3}{*}{2.0} & ou & 820 & 870 & 1000 & 1005 & 950 & 900 \\
\hline & $8 \%$ & 2.2 & 6.0 & 8.5 & 7.5 & 5.0 & 4.2 \\
\hline & Hv10 & 440 & 370 & 350 & 355 & 380 & 400 \\
\hline \multirow{3}{*}{4.0} & ou Mpa & 840 & 990 & 1030 & 1035 & 980 & 920 \\
\hline & $8 \%$ & 2.5 & 7.0 & 9.5 & 8.0 & 6.0 & 5.0 \\
\hline & Hv10 & 460 & 400 & 370 & 375 & 390 & 420 \\
\hline
\end{tabular}


Table 4. Variation of Impact Toughness (IT) For Austempered Ductile Iron At $220^{\circ} \mathrm{C}$ With Variable Ni Content (average of 3 readings)

\begin{tabular}{|c|c|c|c|c|c|c|c|}
\hline \multirow{2}{*}{$\begin{array}{c}\text { Ni\% } \\
\text { content }\end{array}$} & $\begin{array}{c}\text { Mech. } \\
\text { Prop. } \\
\text { (joule) }\end{array}$ & \multicolumn{6}{|c|}{ Holding Time } \\
\cline { 3 - 8 } & (10 min & $30 \mathrm{~min}$ & $1 \mathrm{hr}$ & $2 \mathrm{hrs}$ & $10 \mathrm{hrs}$ & $24 \mathrm{hrs}$ \\
\hline 0.0 & IT & 61 & 64 & 68 & 69 & 62 & 59 \\
\hline 0.5 & IT & 65 & 70 & 73 & 75 & 68 & 66 \\
\hline 1.0 & IT & 69 & 74 & 78 & 80 & 73 & 70 \\
\hline 2.0 & IT & 73 & 78 & 82 & 85 & 77 & 74 \\
\hline 4.0 & IT & 78 & 84 & 87 & 90 & 82 & 86 \\
\hline
\end{tabular}

Table 5. Variation of Impact Toughness (IT) For Austempered Ductile Iron At $400{ }^{\circ} \mathrm{C}$ With Variable $\mathrm{Ni}$ Content (average of 3 readings)

\begin{tabular}{|c|c|c|c|c|c|c|c|}
\hline \multirow{2}{*}{$\begin{array}{c}\text { Ni\% } \\
\text { content }\end{array}$} & $\begin{array}{c}\text { Mech. } \\
\text { Prop. } \\
\text { (joule) }\end{array}$ & \multicolumn{6}{|c|}{ Holding Time } \\
\cline { 3 - 8 } & (10 min & $30 \mathrm{~min}$ & $1 \mathrm{hr}$ & $2 \mathrm{hrs}$ & $10 \mathrm{hrs}$ & $24 \mathrm{hrs}$ \\
\hline 0.0 & IT & 112 & 127 & 130 & 128 & 108 & 106 \\
\hline 0.5 & IT & 115 & 132 & 134 & 130 & 114 & 110 \\
\hline 1.0 & IT & 120 & 136 & 142 & 138 & 117 & 112 \\
\hline 2.0 & IT & 125 & 142 & 145 & 143 & 122 & 115 \\
\hline 4.0 & IT & 130 & 146 & 154 & 148 & 126 & 118 \\
\hline
\end{tabular}




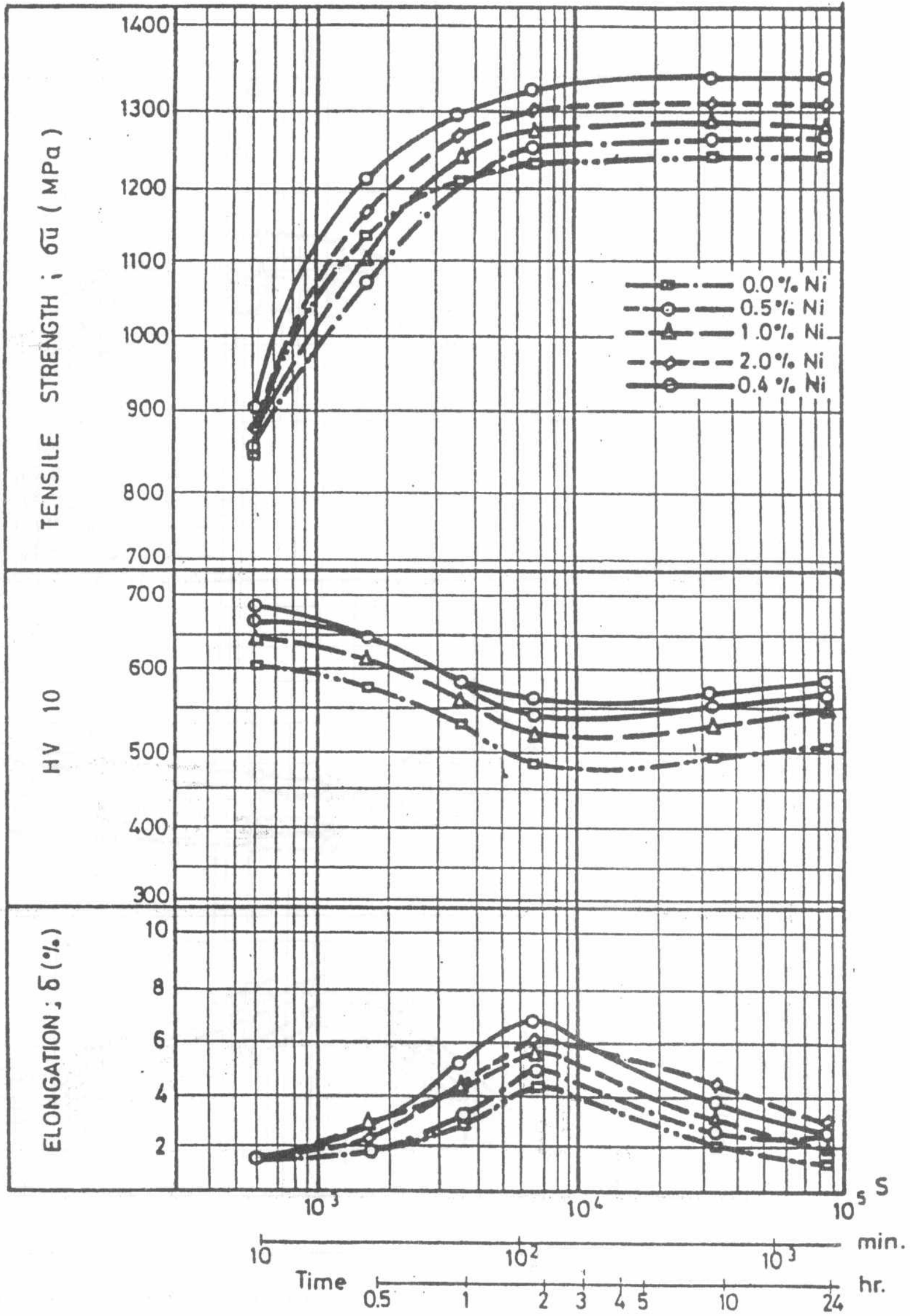

Fig.11. Influence of austempering time on the mechanical properties of alloyed nodular iron austempered at $220^{\circ} \mathrm{C}$ 


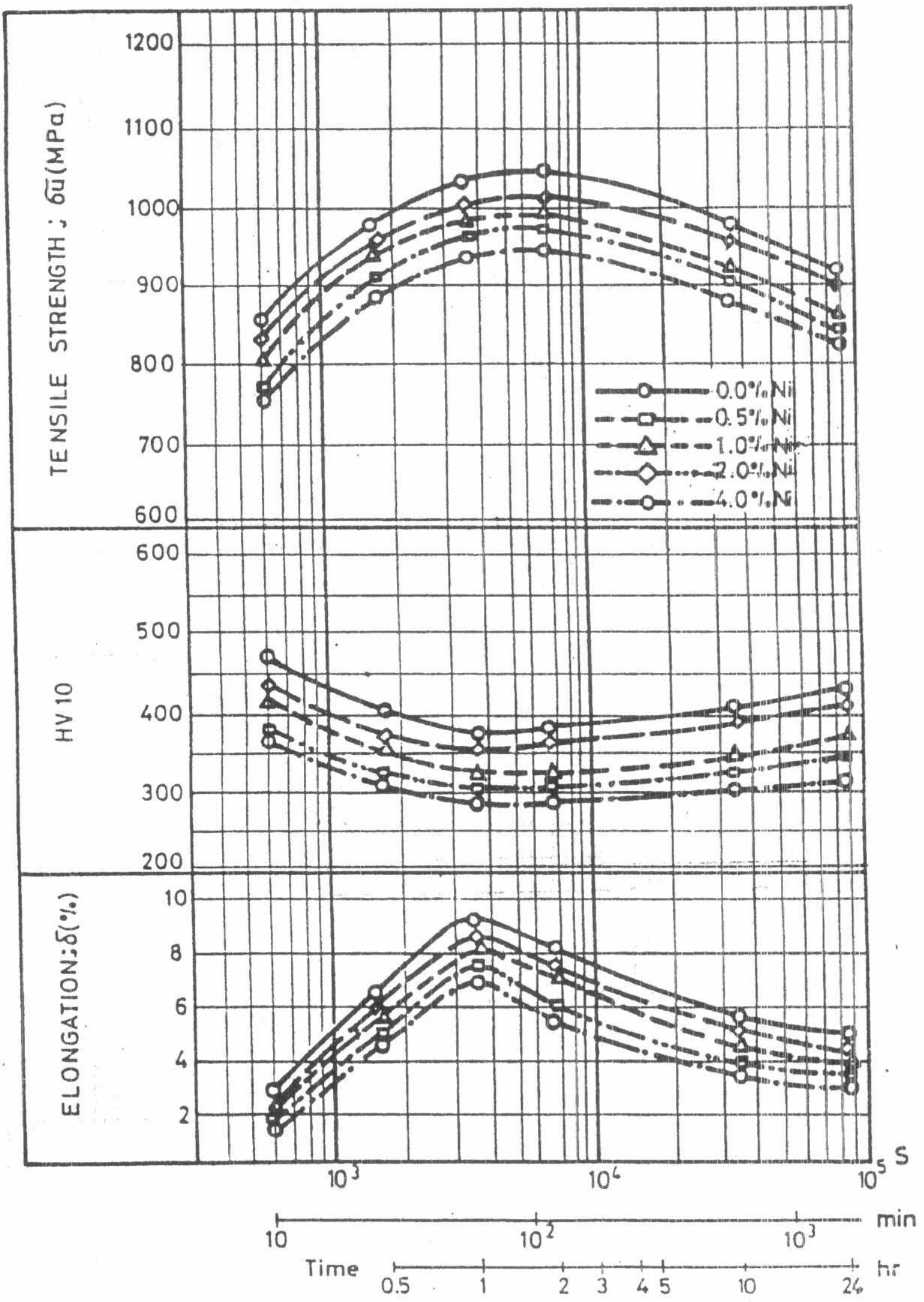

Fig.12. Influence of austempering time on the mechanical properties of alloyed nodular iron austempered at $400{ }^{\circ} \mathrm{C}$ 


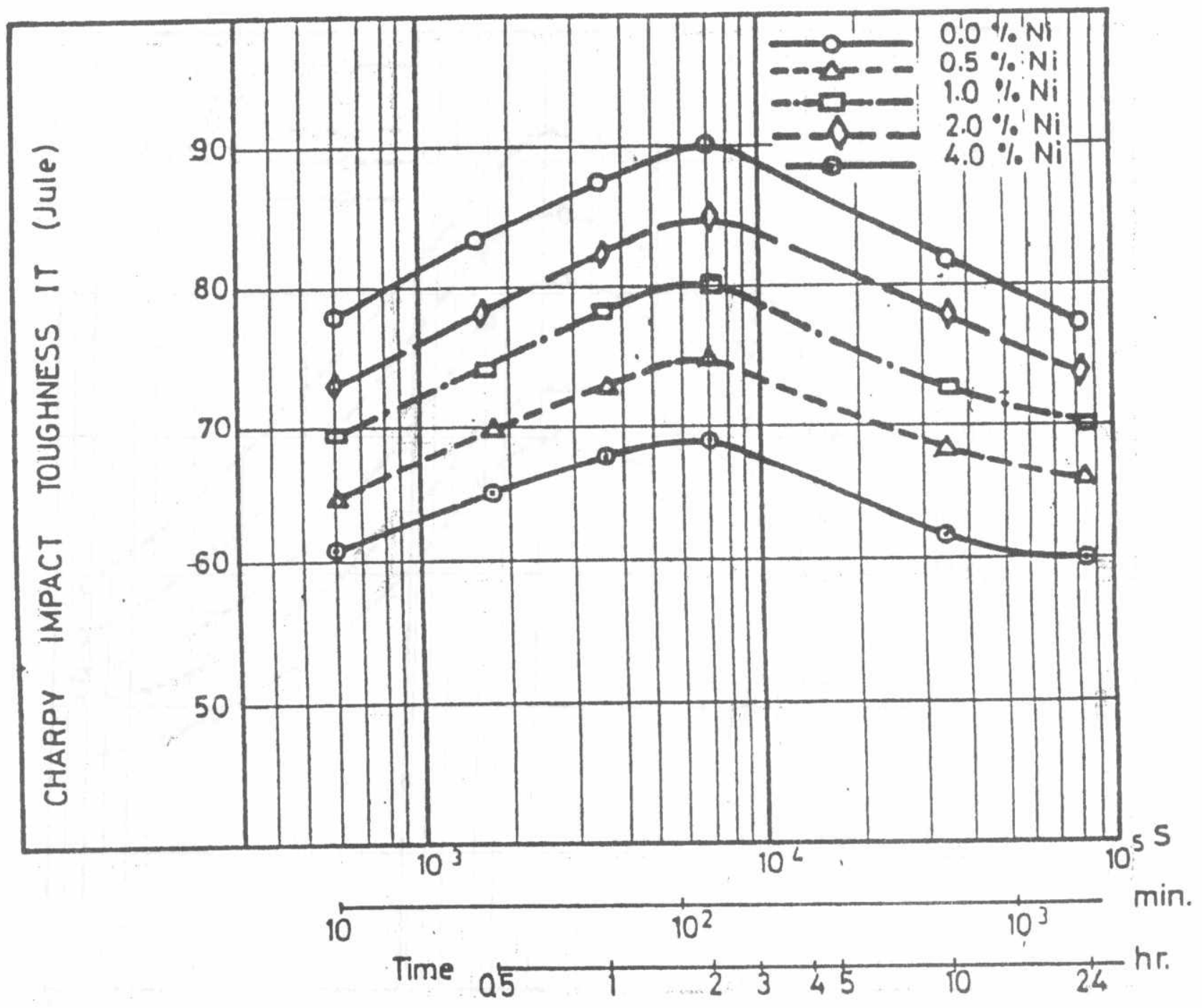

Fig.13. Influence of austempering time on the Charpy $U$-notch impact toughness of D.C.I. austempered at $220^{\circ} \mathrm{C}$. 


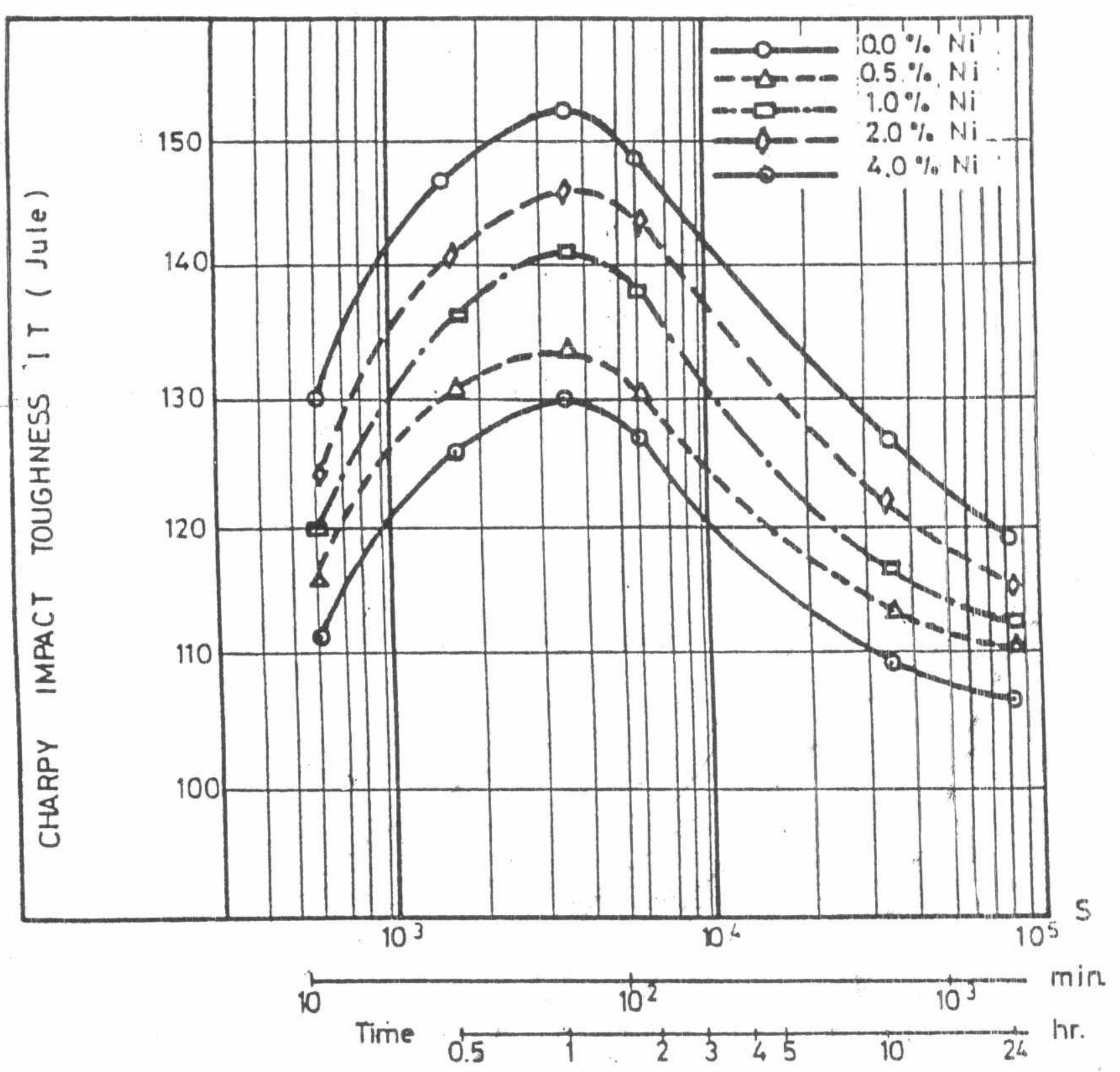

Fig.14. Influence of austempering time on the Charpy $U$-notch impact toughness of D.C.I. austempered at $400^{\circ} \mathrm{C}$. 


\section{REFERENCES:}

[1] J.F.Janwak: Alloying nodular iron with molybdenum, Climax Molybdenum Company, Submitted to the ductile iron society, March 1982.

[2] J.F.Janwak and R.B.Gundlach: Austempering nodular iron for high strength toughness, Technical report, Climax Molybdenum Company, 1981.

[3] R. Le Houillier, G. Begin and A. dube: A study of pecularities of Austenite during the formation of bainite, 1971, Metall Trans., 2, p.2645-2653.

[4] T.Luyendjk and H.Nieswaage: The influence of silicon on toughness of bainitic iron, proc. of the $50^{\text {th }}$ International foundry congress. 1983, cairo.

[5] J.D.Verhoeven, A.EI Sarnagawi, D.P.Cornwell and F.Laabs: A study of austempered ductile cast iron, August 1994.

[6] M.Johansson: Austenitic-Bainitic ductile iron AFS Trans, 1977, 85 P. 117122.

[7] T.Shiokawa: The austempering of ductile cast irons, their mechanical properties and some practical application, Nov. 1978.

[8] E.Dorazil, B.Barta, E.Mansterove, L.Stronsky and A.Huvar: High strength bainitic ductile cast iron, AFS International cast Metals Journal, June 1982, P. 53-62.

[9] Continuous cooling transformation diagrams for ductile cast iron, climax Molybdenum Company, and 1982.

[10] Z. Yicheng et al: Hyoid pinion and ring gears of bainitic nodular iron with shell molded cast teeth, the $46^{\text {th }}$ international Foundry congress, Madrid, October, 1979.

[11] F.S. Rossi and B.K. Gupta: Austempering of nodular cast iron automobile, Metal progress, April 1981, p. 25-31.

[12] J.F. Janwak et al: Technical advance in cast metallurgy, climax molybdenum Company, the $48^{\text {th }}$ international foundry congress, Varna, Bulgaria, 1981. 